TAZKIR: Jurnal Penelitian Ilmu-ilmu Sosial dan Keislaman

Web: jurnal.iain-padangsidimpuan.ac.id/index.php/TZ/

Vol. 05 No. 1 Juni 2019

DOI: http://dx.doi.org/10.24952/tazkir.v5i1.1911

\title{
INTONATION OF STUDENTS IN READING TEXT
}

\section{HIFNI MARINA PADE SIREGAR}

IAIN Padangsidimpuan

Email: hifnimarinasiregar@gmail.com

DOI: http://dx.doi.org/10.24952/tazkir.v5i1.1911

\begin{abstract}
Abstrak
Artkel ini berdasarkan hasil penelitian yang dilakukan berkaitan dengan analisis terhadap kemampuan siswa dalam melakukan atau menggunakan intonasi dalam membaca teks berbasaha Inggris pada mahasiswa Tadris Bahasa Inggris IAIN Padangsidimpuan. Penelitian dilakukan secara kualitatif dalam bentuk deskriptif dengan rekaman sebagai instrument untuk mengumpulkan data yang dilakukan melalui tes dan wawancara. Hasil penelitian menunjukkan bahwa mahasiswa memiliki kemampuan yang rendah dalam menunjukkan intonasi yang benar ketika membaca teks, khususnya pada intonasi yang tinggi
\end{abstract}

Keyword: Linguistics, Intonation, and Rising Intonation

\begin{abstract}
This articles come from the research with the aim is to analyze students' intonation ability by reading a paragraph and to find the difficulties students' intonation of the Second Grade English Education Department IAIN Padangsidimpuan by reading a paragraph. It was a Descriptive Qualitative Method in which the data taken from test and it was recorded. The result was found that students' rising intonation by reading a paragraph of the Second Grade English Education Department IAIN Padangsidimpuan was still low score 56.5. The students got difficult in rising intonation and the dominantly wrong when intonated the text. It is concluded that students' rising intonation by reading a paragraph students of the Second Grade English Education Department IAIN Padangsidimpuan was still low.
\end{abstract}

Keyword: Linguistics, Intonation, and Rising Intonation

\section{INTRODUCTION}

Language has an important position in the life; it is a tool for human being to interest and to communicate in every country or nation. Language is a system of communication by sound, through the organ of speech and hearing 
140 | TAZKIR: Jurnal Penelitian Ilmu-ilmu Sosial dan Keislaman

Vol. 05 No. 1 Juni 2019

among human being of certain group of communication using vocal symbol possessing arbitrary conventional meanings. Through language, human can communicate one with another to express idea, feeling, thoughts and desires.

In Indonesia, English is acknowledged as a foreign language. It became an obligation subject that must be learnt by students from elementary school level up to university level. In studying English, students will learn language skill. Such as writing, speaking, reading and listening skills, which include by language component, such as pronunciation.

Pronunciation is a set of habits of producing sounds. The habit of producing a sound is acquired by repeating it over and over again and by being corrected when it is pronounced wrongly. Having good pronunciation skills is an important part of every ESL (English Second Language) students' ability to communicate in English. Abbas Pourhossein Gilakjani said that by good pronunciation, a speaker is intelligible despite other errors, but with poor pronunciation, understanding a speaker will be very difficult, despite accuracy in other areas. ${ }^{1}$ So, the speakers have to have good pronunciation, so that their speeches will be understandable to the listeners. There are many pronunciation categories that must be learnt by students. For example, phonetics, vowels, syllable, stress and intonation.

Therefore, it is undeniably that intonation learning is necessary for everybody in variety of purposes and needs. However, intonation skill is problematic at the most of students in the aspect of ability or motivation.

In Second Grade of English Education Department IAIN Padangsidimpuan, especially for TBI-1, the lecturer who taught them said that 50 $\%$ of students still have difficulties in pronouncing the words. They were still shy to pronounce the words in English well. They were afraid their friends will laugh them when they pronounce the words. ${ }^{2}$

In addition, they could not spell the word perfectly, because they prefer to listen to the lecturer speaking English rather than practicing their pronunciation directly. Moreover, the researcher interviewed some students who say that learning how to pronounce the words exactly about falling and rising intonation was most difficult one in learning English.

${ }^{1}$ Abbas Pourhossein Gilakjani, English Language Department (Iran: Islamic Azad University, 2011), p.2.

2 Hamka as Pronounciation lecturer in class TBI-1, Private Interview (FTIK Padangsidimpuan: januari 22nd, 2015 at 10.30 a.m). 
Based on the explanation above and problems exist of second grade English Education Department IAIN Padangsidimpuan about students' falling and rising intonation, the researcher is interested in conducting the research entitled Students' Intonation of the Second Grade English Education Department IAIN Padangsidimpuan. Based on the background of the problem above, there were many problems included in intonation learning, such as students could not spell the word perfectly, and there is score in pronounce the words is very poor. Then, the researcher focuses on the problems about intonation, especially for rising intonation. The researcher only focused the problem about the students' rising intonation in sentences at Second Grade of English Education Department IAIN Padangsidimpuan.

\section{THEORETICAL DESCRIPTION}

In conducting research, theories are needed to explain some concepts or terms apply in research concerned. Intonation according to Oxford dictionary is the rise fall meaning of the voice in speaking, especially as this effect the English, some questions have a rising intonation. ${ }^{3}$ So based on the definition above, it will be concluded that intonation is the rise and fall meaning that place in the pitch of the voice in connected in speaking.

Intonation is completely satisfactory, but any attempt at a definition must recognize that the pitch of the voice plays the most important part. Only in vey unusual situations do we speak with fixed, unvarying pitch, and when people speak normally the pitch of our voice is constantly intonation is to listen to the speaker's pitch and recognize what is the doing; this is not an cays thing to do, and it seems to be quite different skill from that acquired in studying segmental phonetics. ${ }^{4}$ So based on the definition above, it will be concluded that intonation is the pitch of the voice. Then, when people speak normally the pitch of our voice constantly changes intonation.

Anas Syafei said that intonation is the tune of what we say. More specifically, it is the combination of musical tones (pitch) on which we pronounce the syllables that make up their speech. Intonation is very important grammatical in distinguishing one type of sentence from another, and it is also important in

\footnotetext{
${ }^{3}$ As.Hornby, Oxford Advanced Learner's Dictionary (New York: Oxford University Press, 2000), p. 1103.

${ }^{4}$ Peter Roach, English Phonetics and Phonology (Cambridge University Press, 2011), p. 150.
} 
signaling the attitude of the speaker in what he is saying. ${ }^{5}$ So based on the definition above, the researcher concludes that the intonation is the combination of musical tones (pitch). Then, people pronounced and make up their speech good. So, based on definition above, the researcher concludes that the intonation is rising and falling of the pitch of our voice as we speak.

There are two kinds of intonation, rising and falling intonation. Rising intonation The voice normally goes up to a high note on the last sentence stress, just as in the rising-falling pattern. The difference between the two lies in the fact that, in the rising intonation, the syllables which follow the rise are pronounced on the high note too. Falling intonations generally denote finality. They are accordingly used in commands, of complete statements not implying any continuation known to the speaker, of questions containing a specific interrogative word, and of the last alternative in alternative questions. ${ }^{6}$ Falling intonation is tune consist of a fall in the voice from a fairly high pitch to very low. ${ }^{7}$ Falling intonation is used for asking and giving information in normal, quiet, unemphatic style. At the same time, falling intonation conveys certain emotions, such as completion, finality, confidence. Falling intonation sounds more categorical, confident, and convincing than rising intonation. Compare the use of the falling tone and the rising tone in the second part of tag questions. ${ }^{8}$ These two intonation will use by the learners or speakers when they are speak or reading in order to make the language sound well.

Language learners should understand what the change of standard patterns may signal, but it is advisable to use standard patterns of falling intonation in your own speech.

\section{RESEARCH METHOD}

This research had conducted at second grade English Department IAIN Padangsidimpuan. The research used the qualitative research in which the researcher tried to understand the phenomenon based on the collection data and analysis of non numerical data. The instrument of collecting data would be used

${ }^{5}$ Drs. Anas Syafei, English Pronunciation: Theory and Practice (Jakarta, 1988), p. 28

${ }^{6}$ Daniel Jones, The Pronunciation of English, (Cambridge University Press 1956), p.152.

7 J. D. O' Connor, Better English Pronunciation, (University of London, 1967), p.141.

${ }^{8}$ Daniel Jones, An Outline of English Phonetics, (New York: Cambridge university press, 1975), p.275. 
in this research are: Test and Interview. After collecting the data, the researcher analyses the data by using Recording the students paragraph in pronouncing rising intonation of Second Grade English Education department IAIN Padangsidimpuan, Transcribing students recording paragraph in pronouncing rising intonation, Describing students' rising intonation of second grade English Education Department IAIN Padangsidimpuan, and Finding the students' difficulties in pronouncing rising intonation.

\section{RESEARCH FINDINGS AND DISCUSSION}

\section{Findings}

\section{Describing Students' Rising Intonation}

The researcher took 15 students as a subject to be analyzed. The Researcher gave a chance or time for students to learn the test. The test is true reading paragraph. The researcher took 15 students for appropriating another students from second grade English Education Department. It was done, based on the objective which to analyze falling and rising intonation of students. So that, 15 students could be appropriate this research, and make it more accurate. They were divided based on the Highest, middle, and lowest ranking. Looking from the data above, the students divided into 6 the highest, 7 the middle and 2 the lowest ranking. They were analyzed by giving test to reading a paragraph. Then, researcher collected their record to analyze their falling and rising intonation.

Based on result of the test, the researcher found that students' rising ability in reading a paragraph were really different. The following description would show every details of their competence. See appendices IV. Based on the data above, It could be concluded that the result of the analysis of students' rising intonation ability was 56.5. Based on the calculating score the students' rising intonation ability in reading a paragraph of the second grade English Education Department was 56,5. So, it can be categorized that the students' rising intonation ability in reading a paragraph of the second Grade English Education Department was still low Score.

\section{The Difficulties of Students' Rising Intonation}

As mentioned before, the describing students' rising ability in reading a paragraph was still enough score. It happened, because of there were some difficulties of students in pronouncing those rising intonation. Based on the 
result of test to second grade students at English Education Departemant IAIN Padangsidimpuan. There were some difficulties that usually faced by students in learning intonation. After describing the data, it was gotten that the value of the mean score of the students' rising ability of the Second Grade Students English Education Department IAIN Padangsidimpuan divided 15 was 56,5 and it can be categorized into low category.

According to the classificationn above, it can be seen that:

1) There was three of the students got E predicate that can be categorized in to very low category. It means that three of the students can be classified to the very low category

2) There were 7 students got $D$ predicate that can be categorized in to low category. It means that seventh of the students can be classified to the low category.

3) There were three students got the $C$ predicate that can be categorized in to enough category. It means that three of the students can be classified to the enough category.

4) There were 2 of the students got B predicate that can be categorized in to good category.It means that 2 of the students can be classified to the good category.

5) No one of the student that can be classification or categorized in to very good category.

\section{DISCUSSION}

The result of this research which the title "Students Rising Intonation Of Second Grade English Education Department IAIN Padangsidimpuan", can be categorized into low category. It can be known from the calculating score (56.5). Based on gave the test to the students and recorded it, almost all of the students got low score, it can be seen from the students' score. Further, based on interview to students, there are some difficulties that faced by students in pronounced rising intonation, such as: the students difficult in rising intonation. Students also faced difficulties or dominantly wrong intoning the words when intonating the text, based on interview to Phonetic and Phonology Lecturer, the writer has found the same answer. The students faced difficulties in intoning rising intonation, because they still shy and not seriously to learn intonation. 
In learning Phonetic and Phonology especially intonation, there were some difficulties that faced by students, the students difficult to understand the rising intonation, and they not understand the different high and low intonation The students felt difficulties to pronounced high and low intonation.

Muhibbin Syah said that learning difficulties can be capronounced by 2(two) factors, they were: the first, internal factor (factors from the child it self) involve; physiology factors such as healty; and psychological factors such as IQ (Inteligence Question). The second, external factors (factor outside the child) involve; social factor such as the relationship with the child's parents; and non social factor such as the tools of learning, and learning condition. ${ }^{9}$

However, the internal factor and external factor influenced the students' difficulties in their pronouncing. First, they faced the difficulties because of their worse mind set or opinion. They believe that pronouncing intonation is difficult subject. Then, they have low enthusiasm and motivation in pronouncing intonation. Lastly, they have not understood yet the explanation given by the lecturer. There are also many difficulties of the students, not only in pronunciation, but also in reading; the students got difficulties in understanding and in pronouncing the English text. ${ }^{10}$ Moreover, there are some factors make the students as the condition, one of them is motivation; while when having high motivation will give good effect to the students' learning. ${ }^{11}$ As a result, there are many aspects influenced by factors external and internal in learning.

To anticipate the learning difficulties, the Phonetic and Phonology lecturer reason were the Phonetic and Phonology lecturer often repeat explain the lesson and give more examples which example about rising intonation. Before the Phonetic and Phonology lecturer gave the new lesson, first the Phonetic and Phonology lecturer gave chance or time students to something left or not clears about the lesson. The Phonetic and Phonology lecturer invite the students to learn by heart about rising intonation. The last, the Phonetic and Phonology lecturer gave task for students. The Phonetic and Phonology lecturer said that

${ }^{9}$ Muhibbin Syah, Psikologi Belajar (Jakarta:Raja Grafindo Persada,2008), p. 182-184.

${ }^{10}$ Eka Sustri Harida, "Students' Ability and Difficulties in Understanding English Text (A Study at English Program IAIN Padangsidimpuan)," Al-Ta'lim 21, no. 3 (2014): 183-88, https://journal.tarbiyahiainib.ac.id/index.php/attalim/article/view/102.

${ }^{11}$ Eka Sustri Harida, "An Evaluation on Students' Reading Motivation and Reading Comprehension of the English Department Students IAIN Padangsidimpuan," Jurnal.Iain-Padangsidimpuan.Ac.Id, accessed June 13, 2019, http://jurnal.iainpadangsidimpuan.ac.id/index.php/TZ/article/view/817. 
146 | TAZKIR: Jurnal Penelitian Ilmu-ilmu Sosial dan Keislaman

Vol. 05 No. 1 Juni 2019

they can study with sing a song minimally one song for a weak without open the book. It can help they to improve their pronunciation especially intonation.

\section{CONCLUSIONS}

After getting research and giving test for 15 students, the researcher concludes that the Students' Rising Intonation of the Second Grade English Education Department IAIN Padangsidimpuan was 56.5. in low category. So, therefore it could be concluded that students' rising ability was still low score and it needed further improvement. Further, the difficulties that were faced by the students in rising intonation of the Second Grade English Education Department IAIN Padangsidimpuan were in rising intonation and the students difficult in intonated the text and dominantly wrong when pronounced the text, the students got difficult in study pronunciation especially intonation, the students got difficulties in pronouncing the English word. 


\section{REFERENCES}

Anas Syafe'i, ,English Pronunciation; Theory and Practice, Jakarta: Departement Pendidikan dan Kebudayaan, 1988

Burns, Anne, Doing Action Research in English Language Teaching, New York: Routledge, 2010

Collins, Beverley and Inger M. Mees, Practical Phonetics and Phonology. Newyork:Library, 1998

Connor, J. D. O', Better English Pronunciation, University of London, 1967

Gay, L.R. \& Peter Airasian.,Educational Research: Compenties for Analysis and Application. USA: Prentice Hall, Incorporate. 2000

Gilakjani, Abbas Pourhossein, English Language Department, Iran: Islamic Azad University,2011

Gimson, A.C, Professor of Phonetics, University Collage London, 1980

Gunlogson, Christine, Rising and Falling Declaratives as Questions in English, University of California,2001

Harida, Eka Sustri. “An Evaluation on Students' Reading Motivation and Reading Comprehension of the English Department Students IAIN Padangsidimpuan." Jurnal.Iain-Padangsidimpuan.Ac.Id. Accessed June 13, 2019. http://jurnal.iain-padangsidimpuan.ac.id/index .php/TZ/article/view 1817.

- - - "Students' Ability and Difficulties in Understanding English Text (A Study at English Program IAIN Padangsidimpuan)." Al-Ta'lim 21, no. 3 (2014): 183-88. https://journal.tarbiyahiainib.ac.id/index.php/attalim/article/ view/102.

H. Prator, Clifford, JR. Betty Wallace Robimett, Manual of American English Pronounciation, University of California, Los Angeles, 1957

Hornby, AS, Oxford Advenced Learner's Dictionary.New York: Oxford University Press, 1995

J. Gordon, Morton, A Manual for Speech Improvement, University of Hawaii, 1961 
148 | TAZKIR: Jurnal Penelitian Ilmu-ilmu Sosial dan Keislaman

Vol. 05 No. 1 Juni 2019

Jones, Daniel, An Outline of English Phonetics, New York: Cambridge university press, 1975

Moleong, Lexy J, Metode Penelitian Kualitatif, Bandung: Remaja Rosda Karya, 2009

Mukhtar, Muhammad. The Influence of Pronounciation Toward Speaking Ability Of The Eleventh Grade Students of MA Musthofawiyah Nguruan Soko - Tuban, Bojonegoro, Unpublished Script, Perpustakaan PGRI Bojonegoro, 2005

Resdilla Pratiwi, An Analysis of Students' Vowels Ability in Singing Maherzain Song "I Believe" at the Eighth Grade in MTs. S NU Batahan, Unpublished Script, Padangsidimpuan IAIN, 2014

Rini Erminawati, The Influence of Mother Tongue to Students' Pronunciation, Unpublished Script, Padangsidimpuan STAIN, 2012

Roach, Peter, English Phonetics and Phonology, Cambridge University Press, 2011

Saifuddin Azwar, Metode Penelitan, Yogyakarta: Pustaka Pelajar, 2004

Sudarwan Danim, , Menjadi Peneliti Kulaitatif, Bandung: Pustaka Setia, 2002

Sugiyono, Metode Peneltian Pendekatan Kuantitatif, Kualitatif, dan R \& D, Bandung: Alfabeta, 2009

Sumadi Suryabrata, Metode Penelitian, Jakarta: Raja Grafindo Persada, 1983

Taqi-ud-Din Al-Hilali and Muhammad Muhsin Khan, Muhammad, Translation of the Meanings of the Noble Qur'an in the English Language, Madinah: King Fadh Complex for the Printing of Holy Qur'an, 1454 